https://doi.org/10.48009/1_iis_2008_105-111

\title{
ONLINE WEB DELIVERY OF A GRADUATE PROJECT MANAGEMENT COURSE: CHALLENGES AND OPPORTUNITIES
}

\author{
Manouchehr Tabatabaei, Information Systems, Georgia Southern University, mtabatab@georgiasouthern.edu \\ Richard Chambers, Information Systems, Georgia Southern University, rchamber@georgiasouthern.edu \\ James Whitworth, Information Systems, Georgia Southern University, jewhitwo@georgiasouthern.edu
}

\begin{abstract}
In addition to in-class delivery of project management courses, many institutions have already started or are beginning to plan the delivery of these courses online. The challenge of offering a course online, especially courses with a heavy emphasis on student interaction and team projects, is well documented in the literature. Therefore, we propose a framework is needed to design and plan an online graduate Project Management course to overcome some of the problems and limitations of online delivery and to take advantage of opportunities online technology can provide. The purpose of this research is to identify components of a framework for online web delivery of a graduate Project Management course by investigating the issues and factors that should be considered in making an online Project Management course effective. The suggested components are based on the literature (which identifies some suggested best practices) and experience presenting an online project management course. Further, a survey was conducted to measure and compare student's perceptions of online courses in general and project management online courses in particular to traditional in-class courses. Assessment of student work indicates little difference in educational outcomes and the survey results do indicate students had an overall positive experience with online courses. However completing team based projects successfully was somewhat more difficult in the online course
\end{abstract}

Keywords: Web Delivery, Graduate Project Management Course

\section{INTRODUCTION}

The number of courses of all types being delivered online is substantially increasing every year along with the number of online degrees (Weisenberg and Hutton 1996; Zang and Nunamaker 2003). In 2006 over 3 million students in the United States had taken at least one online course (Allen
2006). There is an ongoing debate as to the criteria to be used to

determine what courses are more suitable to be offered online as well as ownership and uses of intellectual property created as an online course is developed (Ellin, 2000).

The literature has presented extensively the challenges of offering online courses (Aggarwal and Bento 2000; Howard 2002; Piccoli 2001; Privateer 1999). A survey of the literature in 2006 produced one hundred and six studies on the subject of teaching courses online (Tallent-Runnel 2006) The advantages and disadvantages of offering online courses are debated and the quality of learning in an online environment has been questioned and has been researched (Murphy and Cifuentes 2001; Russell 2007).

More successful online courses appear to be content and material oriented (explicit knowledge) rather than skill and practice oriented (tacit knowledge). Courses emphasizing high levels of interaction and immediate feedback as a part of skill and knowledge transfer appear to be poor candidates for online presentation due to the asynchronous nature of traditional online courses which emphasize text as the communication method. However, there has been success with one on one skills training using video conferencing over the Internet (Campbell, 2004).

Project Management as a course in higher education, both at the undergraduate and graduate levels, is becoming a standard course offering for students in a range of disciplines including business. While the specific skills used will vary, there are a core set of skills and knowledge that is shared by most disciplines. This set of core skills and knowledge has been described by the Project Management Institute (PMI) as part of its continuing effort to create a professional project management community across the various disciplines and industries that use the role of project manager in their activities. The Standish Group issued The CHAOS Report in 1995 providing the results of a 
survey which gathered data on reasons for information technology project failures (a copy is available at http://net.educause.edu/ir/library/pdf/NCP08083B.pdf). While a number of researchers have expressed questions on the methodology (see for instance Glass, 2006) used in creating the report, there have been indications from other researchers that the use of professional project management practices improves the chances of project success.

The primary goal of an introductory project management course is to expose students to professional project management practices by providing a survey of the PMI knowledge areas along with exposure to leadership and soft management skills. The objectives in a project management course typically include not only teaching theory, terms, definitions and new concepts related to the subject but also the transfer of new technical skills in using and applying specialized software as well as managerial skills dealing with people (interpersonal communications theory, dialogue, critical thinking and analysis skills, leadership theory, organizational theory, and team building). Most survey project management courses emphasize the following: how to identify and define tasks using a project planning paradigm, how to use a particular project management software application to create a PERT or GANTT charts with the appropriate kinds of tasks and inter-task linkages, how to use the software application to update a project's PERT or GANTT charts as the project progresses, how to read the resulting charts and analyze the charts to develop changed project plans, and how to develop "soft" managerial and leadership skills.

Most project managers have little legitimate power, relying on reward power, referent power, and expert power (Cobb, 1980) in order to manage a project to a successful conclusion (see also Lee, D., 1995 for similar requirements for IS professionals in general). The successful project manager has both explicit knowledge (Project Management Institute nine subject matter areas of the Project Management Body Of Knowledge), and tacit knowledge (the ability to apply the content of the nine areas as the situation demands through the ability to empathize with and have insight into people). Most project management course objectives and desired learning outcomes go beyond the traditional objective of the student learning "about" the subject, an objective many online web courses have addressed successfully (Leidner 1995). How to teach students the skills and behaviors needed to better communicate, manage, lead, and work with people and teams are significant issues that need to be addressed in order to be successful. These interpersonal skill objectives make offering an online project management course a challenge. Therefore, a framework is needed to design and plan an online graduate Project Management course to overcome some of the problems and limitations of online delivery and to take advantage of some of the opportunities online technology can provide.

Two of the important conclusions of the 2006 survey of the literature on teaching courses online (TallentRunnels 2006) were that courses designed and developed for in-class delivery were not necessarily suitable for the online environment and that a framework or model, based upon quality research, for online courses is needed.

The purpose of this research is to investigate the issues and factors that need to be considered in making an online Project Management course effective and identify components of a framework for online web delivery of a graduate Project Management course.

\section{Potential Components of a Framework for Online Graduate Project Management Course}

A framework for an online graduate project management course would have many similarities to a framework for any online course. Many of the activities involved in any online course such as tests on content, discussion groups, and submission of work products would be the same for a project management course. Since the course content involves softer knowledge such as leadership theory, fruitful discussion forums can be created around the various topic areas allowing students to post comments, short essays, and links to papers or articles on the web. The online platform allows for the creation of a learning community centered in the knowledge area of project management. In many ways an online course platform provides a useful learning area whether the course is online or a classroom course acting as a virtual "war room" in which the students and professor can interact.

Borich (2004) identified five classroom teaching strategies, namely direct instruction, indirect instruction, questioning strategies, self-directed learning, and cooperative learning. These strategies and how they can be adopted to online courses are shown in Table 1 (Horton 2000, Borich 2004). With the help of appropriate IT technology, these 
classroom teaching strategies can also be used in an online teaching environment. 
Table 1- Teaching Strategies for online courses

\begin{tabular}{|c|c|c|}
\hline $\begin{array}{l}\text { How we } \\
\text { learn... }\end{array}$ & $\begin{array}{l}\text { Instructiona } \\
\text { l Strategies }\end{array}$ & $\begin{array}{l}\text { Online } \\
\text { instructional tools }\end{array}$ \\
\hline $\begin{array}{l}\text { We learn by } \\
\text { listening. }\end{array}$ & $\begin{array}{l}\text { Direct } \\
\text { Instruction } \\
\text { and Self- } \\
\text { directed } \\
\text { Instruction }\end{array}$ & $\begin{array}{l}\text { Online audio clips, } \\
\text { audio PowerPoint, } \\
\text { online conferences }\end{array}$ \\
\hline $\begin{array}{l}\text { We learn by } \\
\text { seeing. }\end{array}$ & $\begin{array}{l}\text { Direct } \\
\text { instruction } \\
\text { and Self- } \\
\text { directed } \\
\text { Instruction }\end{array}$ & $\begin{array}{l}\text { PowerPoint Slides, } \\
\text { online video clips, } \\
\text { tutorials }\end{array}$ \\
\hline $\begin{array}{l}\text { We learn by } \\
\text { asking. }\end{array}$ & $\begin{array}{l}\text { Questioning } \\
\text { Strategies } \\
\text { and } \\
\text { Cooperative } \\
\text { Learning }\end{array}$ & $\begin{array}{l}\text { Mentoring in Chat } \\
\text { E-mail / Threaded } \\
\text { discussion among } \\
\text { students, and } \\
\text { between students } \\
\text { and instructors and } \\
\text { tutors. }\end{array}$ \\
\hline $\begin{array}{l}\text { We learn by } \\
\text { exploring, } \\
\text { modeling, } \\
\text { researching, } \\
\text { and } \\
\text { practicing. }\end{array}$ & $\begin{array}{l}\text { Experiential } \\
\text { Learning }\end{array}$ & $\begin{array}{l}\text { Case study, } \\
\text { simulations, } \\
\text { computer-based } \\
\text { activities, hands-on } \\
\text { activities, reflection } \\
\text { assignments }\end{array}$ \\
\hline $\begin{array}{l}\text { We learn by } \\
\text { reading. }\end{array}$ & $\begin{array}{l}\text { Direct } \\
\text { Instruction }\end{array}$ & $\begin{array}{l}\text { Instructor's lectures } \\
\text { in notes, } \\
\text { PowerPoint, Word } \\
\text { or PDF document } \\
\text { format; articles, web } \\
\text { resources, textbook }\end{array}$ \\
\hline
\end{tabular}

(Palloff 1999) provides a number of good suggestions for managing an online course that will create a community of learners. A major point in the book is that interaction via the web is different from classroom interaction; it draws on different skills from both students and professor than the face to face of the classroom. An online course has a way of democratizing the class experience by emphasizing written communication skills as the primary vehicle of expression and by eliminating many social cues such as dress, physical appearance, and body language. An online course also introduces delay in the communication process, a delay between when something is posted, when it is read, and when a response is posted. The major form of establishing that a communication has been heard is to post a response and if the discussion groups are not being updated several times a day with postings from students and the professor there is a tendency for students to drop out of the conversation. The richness of face to face conversation has to be replaced with a rich version of a written conversation.

Coppola (2000) suggests that an important factor for effective online learning are "high-quality, highly motivated students" At the beginning of an online course, the students should complete a self assessment with an instrument such as the "Self Evaluation for Potential Online Students" published on the web by the Illinois Online Network: (http://www.ion.uillinois.edu/resources/tutorials/peda gogy/selfEval.asp)

This gives the student an opportunity to determine if online learning fits their circumstances, lifestyle, and educational needs. The questionnaire raises some basic issues to help the students decide if an online program is right for them. Such a survey also provides a professor with a self assessment as to whether the instructor is comfortable with the activities necessary to deliver an online course. Some example questions are:

Are you comfortable with email, computers, and new technologies?

Are you comfortable communicating in writing?

Are you a self-motivated and self-disciplined person?

The first framework component to consider is the environment (Coppola, Hiltz, Rotter 2002). In the online environment the "same time same place" meeting and work environment of the classroom is replaced by either a "different time different place", completely asynchronous, or a "same time different place", synchronous environment using web based collaborative presentation software possibly including online video or audio conferencing. The preference of students and instructors on this issue are important and is included in the survey. Another approach is the combination of the two environments or hybrid which is also included in the survey.

One important issue is how effective is teaching a project management course in a completely "asynchronous" environment. Courses that are mainly focused on "content" (terms, definitions, concepts and theory) are usually more suitable for this "asynchronous" environment. However, if the objective is also interaction among students and between students and professor to develop good face to face interpersonal skills in communication, dialogue, leadership, management and project teamwork an "asynchronous" environment may not well support some of types of activities such as 
presentations, meetings, interviews, and interrogation of team members as to work status. (Webster and Hackley, 1997) mention several issues with distance learning using television technologies that would appear to be issues for synchronized online classes using Internet technologies as well. Problems mentioned included a feeling of distance from the professor which reduced student attention.

In the proposed framework "Virtual" team-work is recommended to replace the group and team projects normally assigned in a traditional on-site project management class. Interactions between students and between students and the instructor are absolutely necessary in a traditional project management class and are no less essential, although more difficult to accomplish, in an online environment. Students should be given an opportunity in an online course to gain valuable experience working with a real virtual team solving realistic problems.

An important issue for the framework is how to package and deliver the course content. The content of a project management course can be partitioned into major topics along the lines of the Project Management Institute's documentation of the Project Management Body of Knowledge. Each module can cover a major topic from the PMBOK with the various topics linked together with various activities into a cohesive whole. Additional modules can be created on more specific topics such as Function Point analysis, Earned Value, PERT/CPM, Gantt Charts, and financial return on investment analyses just to name a few. Project management software, such as MS Project, can be divided into several modules including an advanced module on how to best use this software.

\section{RESEARCH QUESTIONS AND DESIGN}

One of the authors of this paper taught an online project management course in the fall of 2007. This same course was taught in the spring of 2007 as a traditional in-class course. The instructor and students at this institution have been using the "WebCT VISTA" course management software for several years (see Appendix A for a brief description of this course management, web based software) and were therefore familiar with the product. The same course management software was used in both the traditional and the online project management courses.
The author was somewhat skeptical that a project management course could be effectively provided online. The authors assembled a survey instrument with the goal of answering several questions: (1) what are students' opinions of online courses in general and do students find online courses to be an acceptable alternative to classroom courses, (2) what are students' opinions as to the effectiveness of the chosen online environment, WebCT for delivering an online project management course,. A third question was whether an online format was appropriate for learning the fundamentals of project management.

The student feedback was obtained from a survey of 15 graduate students (MBA, Master of Accounting, and Master of Technology) who took the online Project Management course in the fall of 2007. The survey contained eight open-ended questions that were related to the students' perceptions and personal experiences with online courses. In addition, the survey contained seven questions using a five-point Likert scale from strongly disagree (1) to strongly agree (5) related to the students' opinions on the effectiveness of on line courses.

In addition to the survey that was administered, the researchers reviewed student performance between the two classes. Student performance was assessed similarly between the online presentation of the project management course in Fall of 2007 and the classroom presentation of the course in Spring of 2007. The same assessment tools were used in both classes and the workload in the two classes was comparable.

\section{RESEARCH RESULTS}

The overall grades and students' ability to meet the learning objectives was about the same for the online and in-class courses. This indicates that the online project management course was as effective in educating students about project management as a classroom course since the same assessment tools were used in both classes and the workload was comparable.

The results from the survey are summarized in Tables 2 and 3. First the survey respondents had, on average, taken approximately two courses online, which provided them with some basis for an opinion on the subject.

Overall their experiences with online courses have been positive (average of 3.80) and they indicated they would continue to take online courses (average 
of 4.00). The students seemed to have a slightly positive opinion (average of 3.40) as to whether online courses are as good as in-class courses. Another interesting fact is that the students seemed to believe that not all courses are suitable for online instruction (average of 2.50) and feel that only certain courses should be offered online (average of 3.87). They do feel that the graduate project course should be taught online (average of 3.73)

Table 2: The importance of online courses

\begin{tabular}{|l|l|}
\hline Questions & Average \\
\hline Online courses are as good as traditional in-class courses. & 3.40 \\
\hline My experience with online courses has been very positive. & 3.80 \\
\hline I will continue taking online courses. & 4.00 \\
\hline All courses should be offered online. & 2.50 \\
\hline Only certain courses should be offered online. & 3.87 \\
\hline The graduate project management course should be offered online. & 3.73 \\
\hline The quality of an online course can vary by institution. & 4.33 \\
\hline
\end{tabular}

The results from the student survey related to the positive and negative factors of taking online courses are summarized in Table 3.

Table 3 Student opinions of positive and negative factors related to online courses Positive Factors Related to Online Project Management Course

1. More time flexibility/convenience***

2. Not having to attend classes*

3. Geography not an issue/no commuting

4. Learn at own pace

5. Less time-consuming

6. Encourages the development of alternative communication channels

7. Can access class content from any where/any time***

8. Enhances computer skills that are important in the work place

9. Increases self study skills

10. Can take more classes (solves schedule and conflict problems)

11. Work conflicts (such as travel) are less apt to occur.

\section{Negative Factors Related to Online Project management Course}

1. Less effective class discussions**

2. Communication problems, more difficult to learn what is expected*

3. Team work issues (coordination, communication, cooperation) ${ }^{* * *}$

4. Tendency to procrastinate

5. Less ability to learn from others (less interaction)**

6. Problems with course management software (WebCT)

7. More difficult for teams to synergize

8. Less exposure to professor's personal professional project management experience**

9. $\quad$ No formal lecture

10. Audio/Visual conferencing technology not very good

11. Computer and internet connection required

12. Good time management skills required

\section{***- indicates most often expressed opinion}

The most often expressed positive factor was the increased flexibility and convenience of online courses followed by the ability to learn at your own pace and the ability to access course content any time, any where.
The most significant and often expressed negative factor was team work issues (coordination, communication, cooperation). Since this was a project management 
course it is not surprising that this was an important factor. Two other often mentioned were: less ability to learn from other class members (less effective class discussions) and general communication problems (more difficult to know what is expected). Some students also expressed the view that the online course gave them less exposure and less of an opportunity to learn from the professor's personal professional experience.

\section{CONCLUSIONS, LIMITATIONS, AND FUTURE WORKS}

Overall students seem to like the increased flexibility of online courses but they do think they are losing something important because of the lack of face to face interaction with the professor and other students. Some students have suggested that the quality of online courses can be improved by structuring the course to use communication technology to support audio/video teleconferencing (Horton, 2000).

The opinions of the instructor who taught the project management course both online and as a traditional inclass course in the spring of 2007 were similar to those of the students. By far the most difficult issue was the team work. Students have a hard time working as a team even when face to face meetings are possible. Adding the requirement for "virtual teams" significantly complicated the class. Many of the teams had a hard time cooperating, communicating and coordinating their work. One of the teams had so much conflict that two of the team members dropped the class (the online course had about a $20 \%$ drop rate where a more typical number for graduate classes at this institution is 5\%). In hindsight a serious mistake made by the instructor in teaching the online class was to assume that the methods used in-class to form the teams and get them to work together would work online.

In retrospect, to expect students to automatically know how to work in virtual teams was an unreasonable expectation. Individuals who have experience working in face to face teams still have problems when they switch to a virtual environment. In developing a project management course an important component must be to help the students form and work together in virtual teams.

An attempt was made in the fall 2007 course to use the WebCT “Live Classroom” functionality which allows instructors to add interactive lectures to their courses. Full audio, video and chat capabilities, as well as power point presentations and a whiteboard tool all create a "classroom" feel to any online course. However in the fall of 2007 the video component was not working and the quality and reliability of the audio was not acceptable. Three attempts at holding a live classroom meeting and team presentations failed. Not all of the students attended, many who signed on could not be heard and many could not hear the instructor.

A fall back plan, having the teams prepare audio Power Point presentations which were uploaded to WebCT and made available to all students worked quite well. One problem with this approach was the very large size of the audio files. Another lesson learned from this experience was that any attempt at conferencing (chat, discussion groups, audio and or video) should be limited to small groups (4-6 members). Trying to conference or use the WebCT discussion feature with a class size of 25 does not work.

A question often asked is whether it is easier to prepare and teach an online course compared with a traditional class. The experience from this one example of teaching project management online is, at This paper suggests a need for the development of a framework to successfully offer an effective graduate Project Management course and has offered some components to be used in this framework. Some preliminary least in the course preparation phase, online is much harder. At a minimum the amount of time spent in the fall with the online course was at least $150 \%$ of the time spent on the traditional in-class course.

results and conclusions are:

Students want the added flexibility of taking classes online, especially in graduate programs. Student experiences with online courses have basically been positive.

Project Management presents a special set of problems for an effective online course because of the need to teach skills related to communications, dialogue, critical thinking, interpersonal skills, team building and team work

Teaching strategies for an online project management course should incorporate a modular approach to content delivery along with the following:

Online audio clips, audio Power Point, online conferences (audio and /or video). The course should not be completely asynchronous

Online video clips, tutorials

Mentoring in Chat / E-mail / Threaded discussion among students, and between students and instructors and tutors. 
Case studies, simulations, computer-based activities, hands-on activities, realistic team projects and online team presentations.

Instructor's lectures in notes, syllabus, Power Point slides, Word or PDF document format; articles, web resources, textbook

A component that teaches students how to form and effectively work in a virtual team environment.

The results of this study are limited by the small sample size and single data collection event. The students surveyed were graduate students so the results of this research may not apply to undergraduate students since there are qualitative differences between the two types of students including maturity. The survey of graduate students was conducted only one semester in a single class at this institution therefore the sample size was small. There is some agreement with other research in the area of online courses and the results of this study which lends it some validity. More research is needed to complete this framework and identify its components. More students and faculty members with experience teaching online courses need to be surveyed to learn more about the issues to be addressed and the components to be added to the framework. In addition, the experience captured is of only one faculty member teaching the graduate project management course online only once. The future plan includes conducting a more extensive survey over multiple semesters to increase the sample size, and get inputs of many more faculty members teaching online. The survey will also be conducted at other institutions.

\section{REFERENCES}

1. Aggarwal, A. and Bento, R., (2000), Webbased education, In A. Aggarwasl (Ed.), Webbased learning and teaching technologies: Opportunities and challenges. Hershey, PA: Idea Group.

2. Allen, I. E and Jeff Seaman, (2006),Making the Grade: Online Education in the United States, 2006, Babson Survey Research Group, The Sloan Consortium

3. Borich, G.D. (2004). Effective Teaching Methods. 5th edition. Upper Saddle River, NJ: Pearson.

4. CampBell, C. (2004), Remote piano lessons, in real time. New York Times, March 11, 2004.
5. Cobb, A. T., (1980), Informal influence in the formal organization: perceived sources of power among work unit peers, The Academy of Management Journal, Vol. 23, No. 1. pp. 155161.

6. Coppola, N. W., Hiltz, S. R. and Rotter, N. G., (2000), Becoming a virtual professor: Pedagogical roles and asynchronous learning networks, Journal of Management Information Systems, 18(4), 169-189.

7. Ellin, A. (2000), Online teaching; the battle in cyberspace. New York Times, August 6, 2000.

8. Glass, R. L. (2006). The Standish report: does it really describe a software crisis?. Communications of the ACM, Vol. 49, No. 8. pp. 15-16.

9. Horton, W. (2000). Designing Web-based training. New York, NY: Wiley.

10. Howard, J., (2002), Do College Students Participate More in Discussion in Traditional Delivery Courses or in Interactive Telecourses? A Preliminary Comparison, The Journal of Higher Education, Vol. 73, No. pp. 764-780.

11. Lee, D. M. S., Trauth, E. M., Farwell, D., (1995), The Critical skills and knowledge requirements of IS professionals a joint academic/industry investigation, MIS Quarterly, Vol. 19, No. 3. pp. 313-340

12. Leidner, D. E.; Jarvenpaa, S. L., (1995), The use of information technology to enhance management school education: a theoretical view, MIS Quarterly, Vol. 19, No. 3. pp. 265291

13. Murphy, K. L., \& Cifunentes, L., (2002), Using web tools, collaborating, and learning online, Distance Education, Vol. 22, No. 2, pp. 285305.

14. Palloff, R. M., Pratt, K. (1999). Building learning communities in cyberspace: effective strategies for the online classroom. San Francisco, CA: Jossey-Bass Publishers.

15. Piccoli, G., Ahmad, R., and Ives, B., (2001), Web-based virtual learning environments: a research framework and a preliminary assessment of effectiveness in basic IT skills training. MIS Quarterly, Vol. 25, No. 4. pp. 401-426.

16. Privateer, P., (1999), Academic Technology and the Future of Higher Education Strategic Paths Taken and Not Taken, The Journal of Higher Education, Vol. 70, No. 1. pp. 60-79.

17. Russell, Thomas L., (2007), No Significant Difference Phenomenon, http://www.nosignificantdifference.org 
18. Schwalbe, K., (2005), Information Technology Project Management, Fourth Edition, Thomson Course Technology.

19. Tallent-Runnels, Mary k., et al, (2006),Teaching Courses Online: A Review of the Research, Review of Educational Research, Spring 2006, 76,pp93

20. Webster, J., Hackley, P. (1997). Teaching effectiveness in technology-mediated distance learning. The Academy of Management Journal, Vol. 40, No. 6, pp. 1282-1309.

21. Weisenberg, F., \& Hutton, S., (1996), Teaching a graduate program using computer-mediated conferencing software, Journal of Distance Education, Vol. 11, pp. 83-100.

22. Zang, D., Nunamaker, J. F. (2003), Powering elearning in the new millennium: An overview of e-learning and enabling technology, Information systems Frontiers, Vol. 5, No. 2, pp. 207.

\begin{abstract}
APPENDIX A
WebCT VISTA

A brief introduction to WebCT VISTA web based, course management software can be found at the company's web site http://www.webct.com/service/ViewContent?contentID $=9102515$.
\end{abstract}

